\title{
Faktor-Faktor yang Memengaruhi Realisasi Pembiayaan Mikro (Studi Kasus PT Bank Syariah Mandiri KCP Bogor Merdeka)
}

\author{
Factors Influencing Realization of Micro Financing \\ (Case Study at PT Bank Syariah Mandiri KCP Bogor Merdeka)
}

Samirah Ali ${ }^{*}$ dan Ali Mutasowifin ${ }^{2}$

${ }^{1}$ Bank Syariah Mandiri KCP Bogor Merdeka

J1. Merdeka 63, Bogor; e-mail: samierahalie@gmail.com

${ }^{2}$ Departemen Manajemen, Fakultas Ekonomi dan Manajemen, Institut Pertanian Bogor

Jl. Kamper, Kampus IPB Dramaga Bogor 16680; e-mail: alimu@ipb.ac.id

\begin{abstract}
ABSTRAK
Pembiayaan mikro merupakan produk Bank Syariah Mandiri yang sedang berkembang pesat. Tujuan penelitian ini adalah untuk mengetahui faktor apa yang memengaruhi realisasi pembiayaan mikro serta karakteristik debitur pembiayaan mikro. Dengan analisis deskriptif dapat diketahui bahwa karakteristik debitur pembiayaan mikro didominasi oleh jenis kelamin pria, usia 31-40 tahun, pendidikan SMA, jumlah tanggungan keluarga 2-4 orang, lama usaha di atas 2 tahun, laba bersih per bulan Rp1.000.000-Rp5.000.000, jenis usaha didominasi perdagangan, mayoritas frekuensi pinjaman 1-3 kali, jumlah pembiayaan yang diajukan lebih dari Rp20.000.000, nilai agunan nasabah lebih besar dari Rp50.000.000, dan jenis penggunaan adalah produktif. Menggunakan analisis regresi linear berganda dan melakukan uji $\mathrm{F}$ serta Uji T pada $\alpha=5 \%$ terdapat tiga peubah yang secara nyata memengaruhi realisasi pembiayaan mikro, yaitu jenis usaha (perdagangan), jumlah pembiayaan yang diajukan dan nilai agunan.
\end{abstract}

Kata kunci: karakteristik debitur, pembiayaan mikro, realisasi pembiayaan

\section{ABSTRACT}

Microfinance is one popular product of Bank Syariah Mandiri. The purpose of this study is to know factors that influence the realization of microfinance as well as the characteristics of microfinance debitors. Characteristics of microfinance debitors are dominated by male, age 31-40 years old, high school education, 2-4 people dependents family, over 2 years age of business, net income per month from $\mathrm{Rp} 1,000,000$ to Rp5,000,000, dominated by trading companies, 1-3 times of borrowing frequency, amount of financing is more than Rp20,000.000, value of collateral is more than Rp50,000,000, and purpose of financing is for productive activities. Using multiple linear regression analysis, $\mathrm{F}$ test and T test at $\alpha=5 \%$ there are three variables affect the realization of microfinancing, namely type of business (trade), the amount of financing proposed and value of collateral.

Key words: characteristics of debitor, microfinance, realization of financing

\section{PENDAHULUAN}

Usaha Mikro, Kecil dan Menengah (UMKM) memiliki peranan penting dalam perekonomian Indonesia. UMKM mencakup $99,99 \%$ dari total pelaku usaha di Indonesia atau sebanyak 52,76 juta unit (BPS, 2009). Tabel 1 menunjukkan data perkembangan jumlah pelaku usaha menurut skala usaha tahun 2010-2011.

Pengembangan UMKM masih menghadapi kendala, seperti rendahnya kemampuan dalam pemasaran, teknologi, dan dalam mengakses pembiayaan dari perbankan. Kendala UMKM dalam memperoleh pembiayaan perbankan bisa

\footnotetext{
*) Korespondensi:

Bank Syariah Mandiri KCP Bogor Merdeka; Jl. Merdeka 63, Bogor; e-mail: samierahalie@gmail.com
} 
ditinjau dari sisi permintaan dan penawaran. Dari sisi permintaan, pada umumnya, UMKM tidak memiliki informasi keuangan yang transparan dan terorganisasikan dengan baik, sehingga pemberi pembiayaan menemui kesulitan dalam memperoleh informasi mengenai kondisi keuangan dan usaha UMKM. Hal tersebut membuat bank kesulitan meminimalisasi risiko default atas pembiayaan yang disalurkan kepada UMKM.

UMKM sangat membutuhkan pembiayaan yang berkarakteristik mudah, cepat, sesuai dan dekat (Nawai dan Shariff, 2011). Namun, aturan main pada skim pembiayaan formal bersifat rigid, sementara UMKM banyak memiliki keterbatasan. Oleh karena itu, sumber-sumber pembiayaan informal lebih akrab dan menjadi alternatif meskipun diketahui bahwa sumber ini memungut bunga pinjaman lebih tinggi (Nurmanaf, 2007).

Salah satu bank yang terfokus menyalurkan pembiayaan kepada UMKM adalah Bank Syariah Mandiri (BSM), yang memiliki market share $40 \%$ di perbankan syariah. BSM memfokuskan perhatian pada pembiayaan mikro dibandingkan dengan pembiayaan lainnya. Number Of Account (NOA) tabungan di BSM sebanyak 3.565.432 nasabah yang tersebar di seluruh Indonesia, sementara yang membutuhkan pembiayaan mikro 778.600.200 nasabah.

BSM Kantor Cabang Pembantu (KCP) Merdeka Bogor adalah salah satu cabang yang memberikan pelayanan nasabah mikro di wilayah Bogor yang memiliki aset terbesar di antara KCP lain di wilayah Bogor dengan jumlah nasabah 10.782 orang. Untuk terus memastikan penyaluran pembiayaan yang hati-hati, BSM KCP Bogor Merdeka terus melakukan perbaikan, salah satunya perbaikan pengelolaan risiko pembiayaan, terutama penyeleksian calon debitur agar dapat meningkatkan mutu dan kuantitas pembiayaan.
Selain itu, dari 112 nasabah pembiayaan mikro di BSM KCP Bogor Merdeka, 80 nasabah $(71 \%)$ menerima realisasi pembiayaan lebih rendah dari pengajuan, sedangkan yang sesuai dengan pengajuan hanya 32 nasabah (29\%). Dengan kondisi ini, BSM KCP Bogor Merdeka perlu menentukkan langkah yang tepat guna meningkatkan mutu pembiayaan mikro, sehingga pertumbuhan pembiayaan dapat meningkat.

Dengan demikian, rumusan masalah dapat disusun sebagai berikut:

1. Bagaimanakah karakteristik debitur pembiayaan Mikro BSM KCP Bogor Merdeka?

2. Faktor-faktor apakah yang memengaruhi realisasi pembiayaan Mikro BSM KCP Bogor Merdeka?

\section{METODE PENELITIAN}

Faktor-faktor yang memengaruhi realisasi pembiayaan mikro BSM ini didasarkan pada prinsip 5C, yaitu character, capacity, capital, collateral, dan condition of economic (Kasmir, 2013). Berdasarkan pada prinsip 5C ini pemodelan dalam mengestimasi faktor-faktor yang memengaruhi realisasi pembiayaan mikro BSM ditetapkan dengan memodifikasi prinsip 5C.

Peubah yang diturunkan dari prinsip 5C meliputi karakteristik individu, usaha, dan pembiayaan. Karakteristik individu meliputi peubah umur, jenis kelamin, jumlah tanggungan dan pendidikan. Karakteristik usaha meliputi peubah lama usaha, tingkat laba bersih per bulan, dan jenis usaha. Untuk karakeristik pembiayaan meliputi peubah frekuensi pinjaman, jumlah pembiayaan yang diajukan, nilai agunan dan jenis penggunaan pembiayaan.

Tabel 1. Perkembangan jumlah pelaku usaha menurut skala usaha Tahun 2010-2011

\begin{tabular}{|c|c|c|c|c|c|c|c|}
\hline \multirow[b]{2}{*}{ No } & \multirow[b]{2}{*}{ Skala Usaha } & \multicolumn{2}{|c|}{ Tahun 2010} & \multicolumn{2}{|c|}{ Tahun 2011} & \multicolumn{2}{|c|}{ Perkemb angan } \\
\hline & & $\begin{array}{l}\text { Jumlah } \\
\text { (unit) }\end{array}$ & $\begin{array}{c}\text { Pangsa } \\
(\%)\end{array}$ & $\begin{array}{l}\text { Jumlah } \\
\text { (unit) }\end{array}$ & $\begin{array}{c}\text { Pangsa } \\
(\%)\end{array}$ & $\begin{array}{c}\text { Jumlah } \\
\text { (unit) }\end{array}$ & $\begin{array}{c}\text { Pangsa } \\
(\%)\end{array}$ \\
\hline 1 & Usaha Mikro & 53.207 .500 & 98,85 & 54.559 .969 & 99 & 1.352 .469 & 2,54 \\
\hline 2 & Usaha Kecil & 573.601 & 1,07 & 602.195 & 0,91 & 28.594 & 4,98 \\
\hline 3 & Usaha Menengah & 42.631 & 0,08 & 44.28 & 0,08 & 1.649 & 3,87 \\
\hline A. & $\begin{array}{l}\text { Total Usaha Mikro, } \\
\text { Kecil, dan } \\
\text { Menengah } \\
\text { (UMKM) }\end{array}$ & 53.823 .732 & 99,99 & 55.206 .444 & 99,99 & 1.382 .712 & 2,57 \\
\hline $\mathrm{B}$. & Usaha Besar (UB) & 4.838 & 0,01 & 4.952 & 0,01 & 114 & 2,35 \\
\hline $\begin{array}{l}\text { Jun } \\
(\mathrm{A}+\end{array}$ & $\begin{array}{l}\text { Iah Unit Usaha } \\
\text { 3) }\end{array}$ & 53.828 .570 & & 55.211 .396 & & 1.382 .826 & 2,57 \\
\hline
\end{tabular}


Berdasarkan karakteristik individu dapat diketahui pengaruh nyata peubah independen, yaitu peubah umur, jenis kelamin, jumlah tanggungan dan pendidikan. Karakteristik usaha juga digunakan untuk mengetahui pengaruh peubah lama usaha, tingkat laba bersih per bulan, dan jenis usaha. Sementara, peubah frekuensi pinjaman, jumlah pembiayaan yang diajukan, nilai agunan dan jenis penggunaan pembiayaan dipilih mewakili karakteristik pembiayaan.

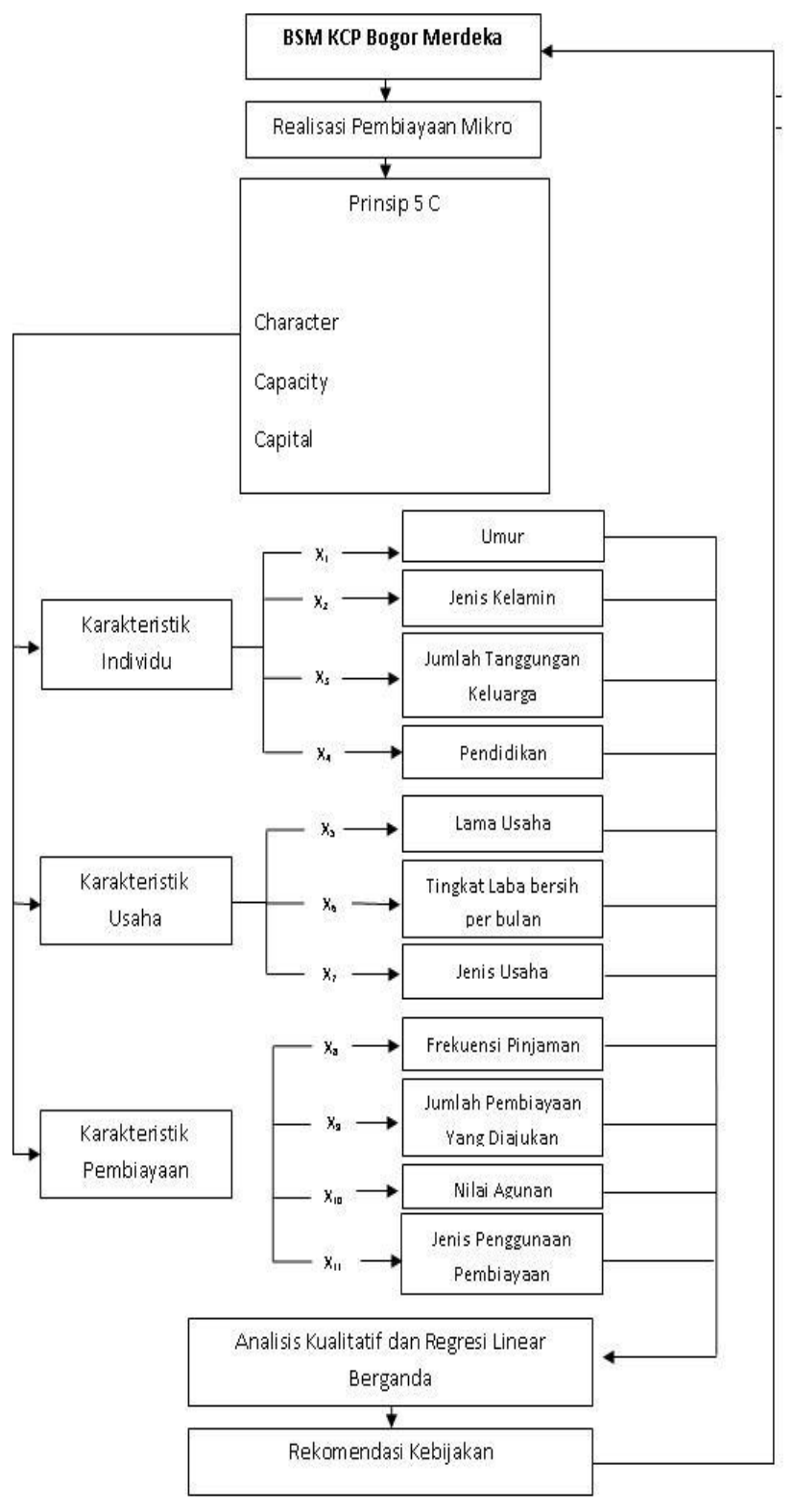

Gambar 1. Kerangka pemikiran penelitian

Dengan mengetahui peubah karakteristik yang memengaruhi realisasi pembiayaan mikro tersebut, diharapkan BSM KCP Bogor Merdeka dapat memformulasikan langkah strategik untuk meningkatkan realisasi pembiayaan mikro.
Berbeda dengan penelitian yang dilakukan oleh Lubis dan Rachmina (2011) yang menggunakan beberapa faktor yang memengaruhi realisasi dan pengembalian kredit usaha rakyat (KUR) dengan menggunakan Analisis Regresi Linear Berganda dan Analisis Logistik Biner. Teknik pengolahan data dilakukan dengan analisis faktor-faktor yang memengaruhi realisasi pembiayaan mikro dengan metode Regresi Linear Berganda, yang merupakan model analisis untuk mengetahui pengaruh peubah-peubah independen berskala metrik (dengan peubah yang belum berskala metrik diubah menjadi peubah boneka) terhadap peubah dependen yang juga berskala metrik (Nazir, 2003). Model ini merupakan model terbaik dalam memprediksi arah, besar koefisien dan sensitivitas perubahan peubah dependen karena perubahan peubah-peubah independen.

Estimasi model untuk analisis faktor-faktor yang memengaruhi realisasi pembiayaan mikro berdasarkan pada karakteristik individu, karakteristik usaha, dan kakteristik pembiayaan yaitu:

$$
\hat{Y}=\beta_{0}+\beta_{1} X_{1}+\beta_{2} X_{2}+\cdots+\beta_{11} X_{11 \ldots \ldots \ldots . .(1)}
$$

Keterangan :

$$
\begin{aligned}
& \hat{Y}=\text { Peubah dependen, yaitu jumlah } \\
& \text { realisasi pembiayaan (Rp) } \\
& \text { Bo } \quad=\text { konstanta atau intersept model garis } \\
& \text { regresi } \\
& X_{1}, \ldots, X_{11}=\text { Peubah independen } \\
& X_{1} \quad=\text { usia (tahun) } \\
& X_{2} \quad=\text { jenis kelamin, peubah boneka }(\text { pria }=1 \\
& \text { dan wanita }=0 \text { ) } \\
& X_{3} \quad=\text { jumlah tanggungan (orang) } \\
& X_{4} \quad=\text { pendidikan (tingkat pendidikan) } \\
& \mathrm{X}_{5} \quad=\text { lama usaha (tahun) } \\
& X_{6} \quad=\text { tingkat laba bersih per bulan }(\mathrm{Rp}) \\
& X_{7} \quad=\text { jenis usaha (jenis usaha) } \\
& \mathrm{X}_{8} \quad=\text { frekuensi pinjaman (kali) } \\
& \mathrm{X}_{9} \quad=\text { jumlah pembiayaan yang diajukan } \\
& (\mathrm{Rp}) \\
& X_{10}=\text { nilai agunan }(\mathrm{Rp}) \\
& X_{11}=\text { jenis penggunanan pembiayaan } \\
& \text { (penggunaan pembiayaan) } \\
& \beta_{1, . .} \beta_{11}=\text { koefisien peubah independen }
\end{aligned}
$$

\section{HASIL DAN PEMBAHASAN}

Warung mikro BSM beroperasi mulai tahun 2009. Saat ini oulet warung mikro di seluruh indonesia baik out branch (sales outlet) maupun in branch sebanyak 522 outlet (BSM, 2013). Untuk wilayah Bogor saat ini terdapat 6 outlet in branch dan 1 outlet out branch. 
Plafon pembiayaan mikro mulai Rp2.000.000 hingga Rp100.000.000 dengan jangka waktu pembiayaan maksimum 3 tahun (untuk wiraswasta) dan maksimum 5 tahun (untuk karyawan). Struktur organisasi warung mikro BSM terdiri dari 1 Kepala Warung Mikro (KWM), 1 Asisten Analis Mikro (AAM), 1 Mentor Usaha (MU), 3 Pelaksana Marketing Mikro (PMM) dan 1 Admin Pembiayaan Mikro (APM). Menurut Anggraini dan Nasution (2013) peranan kredit usaha rakyat atau kredit mikro sangat membantu dan berperan penting dalam pengembangan UMKM.

\section{Deskripsi Responden}

Dalam perealisasian pembiayaan oleh pihak Bank yang mengacu pada prinsip 5C, nasabah dapat dideskripsikan menjadi karakteristik individu, karakteristik usaha dan karakteristik pembiayaan. Data nasabah dalam penelitian ini terdiri dari 112 nasabah produktif (wiraswasta) Warung Mikro BSM KCP Bogor Merdeka yang aktif dari 1 September 2010 sampai dengan 31 Maret 2013. Kemudian dilakukan pengolahan data, dengan beberapa data yang harus dibuang (pencilan), karena menyebabkan data tidak menyebar normal. Data yang dibuang sebanyak 7 responden, sehingga responden yang terlibat dalam penelitian ini berjumlah 105 nasabah.

\section{Karakteristik Individu}

Salah satu prinsip dalam 5C adalah character dan sangat penting dalam persetujuan pembiaya- an. Karakteristik individu terbagi menjadi empat peubah, yaitu umur, jenis kelamin, jumlah tanggungan keluarga, dan pendidikan yang menjadi dasar penilaian karakter nasabah.

\section{Karakteristik Usaha}

Karakteristik usaha sangat berpengaruh terhadap persetujuan pembiayaan. Dalam prinsip 5C biasa dikenal dengan sebutan capacity, yaitu kemampuan nasabah dalam mengelola usahanya dan menyangkut kemampuan nasabah untuk membayar kewajibannya. Karakteristik usaha dibagi menjadi tiga, yaitu lama usaha, tingkat laba bersih per bulan, dan jenis usaha.

\section{Karakteristik Pembiayaan}

Karakteristik pembiayaan dibagi menjadi empat, yaitu frekuensi pinjaman, jumlah pembiayaan yang diajukan, nilai agunan (collateral) dan jenis penggunaan pembiayaan.

\section{Analisis Realisasi Pembiayaan Mikro}

Dalam penelitian ini terdapat sebelas faktor yang diduga memengaruhi realisasi pembiayaan mikro di BSM KCP Bogor Merdeka, yaitu Umur $\left(X_{1}\right)$, Jenis Kelamin $\left(X_{2}\right)$, Jumlah Tanggungan Keluarga $\left(X_{3}\right)$, Pendidikan $\left(X_{4}\right)$, Lama Usaha $\left(X_{5}\right)$, Tingkat Laba Bersih Per Bulan $\left(X_{6}\right)$, Jenis Usaha $\left(X_{7}\right)$, Frekuensi Pinjaman $\left(X_{8}\right)$, Jumlah Pembiayaan yang Diajukan $\left(X_{9}\right)$, Nilai Agunan $\left(X_{10}\right)$, dan Jenis Penggunaan Pembiayaan $\left(\mathrm{X}_{11}\right)$.

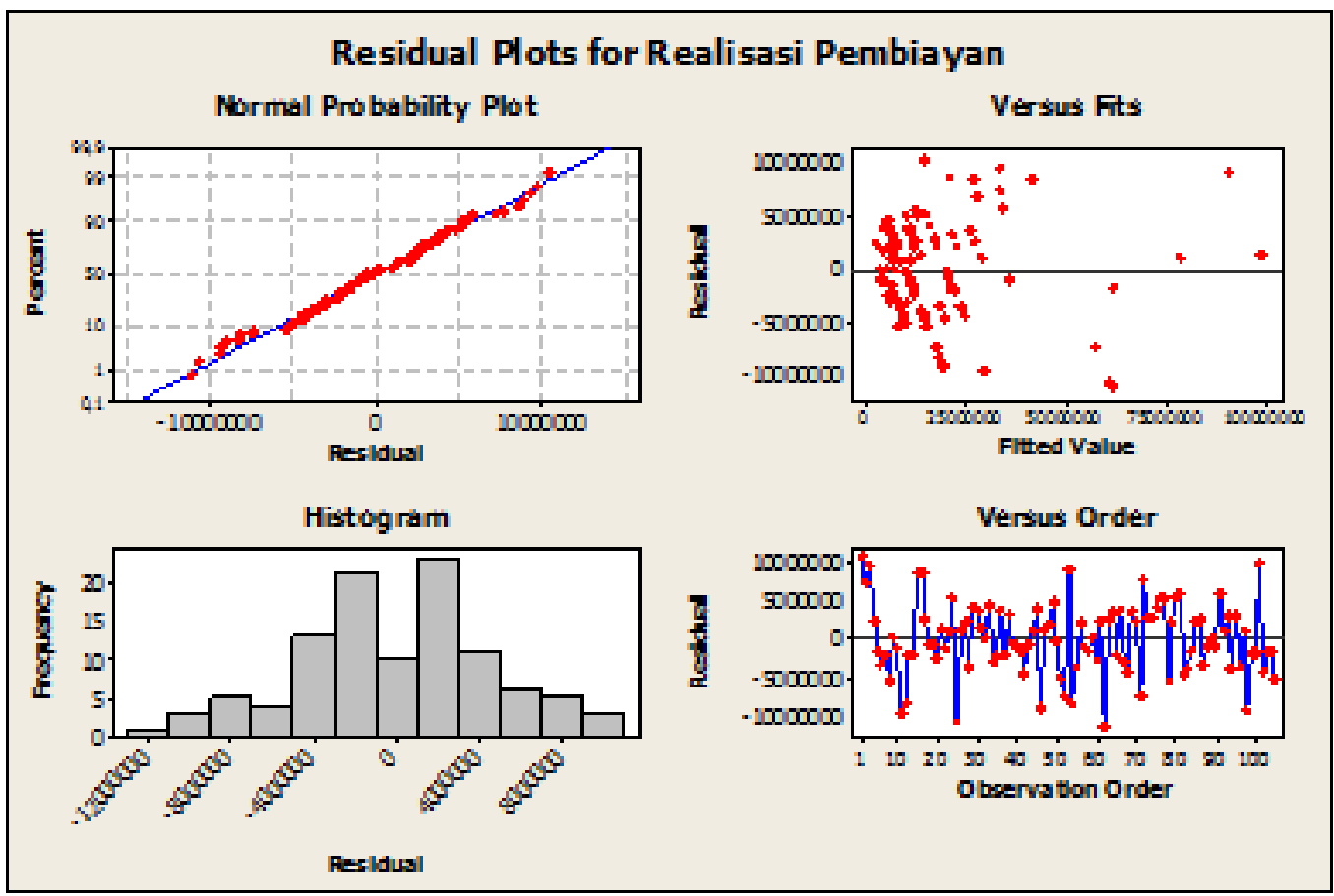

Gambar 2. Hasil uji normalitas dan homogenitas 
Untuk membuat persamaan regresi linear berganda diperlukan beberapa asumsi mendasar, yaitu normalitas, homogenitas, multikolinearitas dan autokorelasi (Sunyoto, 2011). Pengolahan data dalam penelitian ini menggunakan Minitab 14 (Iriawan dan Astuti, 2006). Hasil pengolahan menunjukkan bahwa data memiliki sebaran normal (Gambar 2). Dan untuk asumsi homogenitas terpenuhi dalam gambar residual plots (versus fits) pada Lampiran yang memiliki lebar pitaan sama, sehingga dapat dikatakan bahwa data yang diuji homogen.

Dalam penelitian ini terdapat satu peubah dependen dan sebelas peubah independen. Pada saat dilakukan pengujian dari peubah-peubah tersebut terdapat salah satu peubah yang menghasilkan data yang kurang akurat dengan kondisi pada kenyataan.

Dari hasil pengolahan data, peubah yang tidak sesuai adalah DPP (jenis penggunaan pembiayaan) menghasilkan positif untuk penggunaan konsumtif. Artinya jika pengajuan nasabah konsumtif, maka realisasi pembiayaan akan naik, karena bernilai positif, tetapi pada kenyataan bank akan lebih cenderung merealisasikan pembiayaan jika kebutuhan nasabah untuk produktif. Hal tersebut terjadi, karena data yang diperoleh berbanding jauh, yaitu 2:103, sehingga faktor jenis penggunaan pembiayaan dihilangkan dan menghasilkan hasil olahan regresi berganda yang dapat dilihat pada Tabel 2.

Dalam penelitian ini nilai Variance Inflation Factor (VIF) pada tiap-tiap peubah tertinggi, yaitu jumlah pembiayaan yang diajukan 3,540. Karena nilai VIF lebih kecil dari 10, maka tidak terdapat hubungan yang kuat antara peubah bebas atau tiap-tiap peubah bebas tidak saling memengaruhi satu sama lainnya (bebas multikolinearitas).

\section{Uji F (simultan)}

Uji F pada dasarnya menunjukkan apakah semua peubah bebas yang dimasukkan dalam model mempunyai pengaruh secara bersamasama (simultan) terhadap peubah terikatnya.

Dari hasil analisis seperti pada Tabel 3 dapat disimpulkan bahwa secara simultan peubah umur, jenis kelamin, jumlah tanggungan keluarga, pendidikan, lama usaha, tingkat laba bersih per bulan, jenis usaha, frekuensi pinjaman, jumlah pembiayaan yang diajukan, serta nilai agunan berpengaruh secara nyata terhadap realisasi pembiayaan, karena nilai p-value $(0,000)$ $<$ alpha $(0,05)$, maka tolak Ho sehingga minimal ada satu peubah atau peubah bebas berpengaruh nyata terhadap peubah tidak bebas (Realisasi Pembiayaan).

\section{Uji T (parsial)}

Uji $t$ digunakan untuk menguji nyatanya regresi tiap-tiap peubah independen. Jika nilai probabilitas lebih kecil dari tingkat nyata yang diharapkan $(\alpha=5 \%)$, maka terdapat pengaruh nyata peubah dependen dengan independennya.

Berdasarkan hasil uji $\mathrm{t}$ diketahui peubahpeubah apa yang memengaruhi realisasi pembiayaan mikro pada BSM KCP Bogor Merdeka. Berdasarkan hasil penelitian (Tabel 2) pada $\alpha=5 \%$ terdapat tiga peubah yang memengaruhi realisasi pembiayaan, yaitu jenis usaha (perdagangan), jumlah pembiayaan yang diajukan dan nilai agunan dengan nilai $p$-value berturut-turut $(0,044$; $0,000 ; 0,000)$.

\section{Uji $\mathrm{R}^{2}$ (Koefisien Determinasi)}

Uji $R^{2}$ menunjukkan seberapa besar model mampu menjelaskan variabilitas peubah independen (Gujarati, 2007). $\mathrm{R}^{2}$ adalah koefisien determinasi yang mengukur besarnya pengaruh peubah independen secara bersama-sama terhadap peubah dependen.

Dari hasil penelitian pada Tabel 1 diketahui bahwa R-Sq $($ adj) $=92,4 \%$, yang artinya kemampuan seluruh peubah $\mathrm{X}$ mampu menjelaskan secara nyata keragaman perealisasian pembiayaan $92,4 \%$ dan sisanya $(7,6 \%)$ dijelaskan oleh faktorfaktor lain.

Dalam penelitian ini, peubah terbagi menjadi peubah dependen (yang dipengaruhi) dan variabel independen (yang memengaruhi), yaitu:

\section{Peubah Dependen}

Dalam penelitian ini yang menjadi peubah dependen adalah jumlah realisasi pembiayaan mikro pada PT Bank Syariah Mandiri KCP Bogor Merdeka. Plafon mikro maksimum Rp100.000.000, sedangkan besaran realisasi pembiayaan mikro berfluktuasi, dengan rataan realisasi pembiayaan mikro menurut penelitian Rp19.016.190.

\section{Peubah Independen}

Dalam penelitian ini peubah independen yang memengaruhi realisasi pembiayaan mikro pada $\alpha=5 \%$ terdapat tiga peubah, yaitu jenis usaha (perdagangan), jumlah pembiayaan yang diajukan dan nilai agunan. Berdasarkan hasil analisis regresi dari data panel pada Tabel 2 dapat disusun persamaan regresi sebagai berikut: 
Tabel 2. Hasil pengujian model regresi linear berganda

\begin{tabular}{|c|c|c|c|c|c|}
\hline Predictor & Coef & SE Coef & $\mathbf{T}$ & $\mathbf{P}$ & VIF \\
\hline Constant & 3118844 & 3328863 & 0,94 & 0,351 & \\
\hline Umur & 1621 & 73479 & 0,02 & 0,982 & 1,328 \\
\hline DJ (jenis kelamin) & -2035874 & 1147885 & $-1,77$ & 0,080 & 1,362 \\
\hline Jumlah Tanggungan Keluarga & -258883 & 479036 & $-0,54$ & 0,590 & 1,642 \\
\hline DP1 (pendidikan) & 1945254 & 2656051 & 0,73 & 0,466 & 1,389 \\
\hline DP2 & -50376 & 1788319 & $-0,03$ & 0,978 & 2,222 \\
\hline DP3 & 585002 & 1467811 & 0,40 & 0,691 & 2,339 \\
\hline DP4 & 75110 & 2239732 & 0,03 & 0,973 & 1,707 \\
\hline Lama Usaha (tahun) & 196370 & 117117 & 1,68 & 0,097 & 1,426 \\
\hline Tingkat laba bersih per $b$ & 0,2715 & 0,1372 & 1,98 & 0,051 & 1,630 \\
\hline DU1 (jenis usaha) & -3270250 & 1597424 & $-2,05$ & $0,044^{*}$ & 2,613 \\
\hline DU2 & -935714 & 1894217 & $-0,49$ & 0,623 & 2,976 \\
\hline Frekuensi Pinjaman & -27226 & 288225 & $-0,09$ & 0,925 & 1,320 \\
\hline Jumlah Pembiayaan yang diajukan & 0,50981 & 0,03338 & 15,27 & $0,000^{*}$ & 3,540 \\
\hline Nilai Agunan & 0,08217 & 0,02243 & 3,66 & $0,000^{*}$ & 3,178 \\
\hline $\mathrm{R}-\mathrm{Sq}=93,4 \%$ & $-5 q(a)$ & & & & \\
\hline
\end{tabular}

Ket : $\left(^{*}\right)$ nyata pada taraf $5 \%$

Tabel 3. Hasi uji F

Analysis of Variance

\begin{tabular}{lrcccc}
\hline Source & DF & SS & MS & F & P \\
\hline Regression & 14 & $3,09469 \mathrm{E}+16$ & $2,21049 \mathrm{E}+15$ & 91,42 & 0,000 \\
Residual Error & 90 & $2,17625 \mathrm{E}+15$ & $2,41806 \mathrm{E}+13$ & & \\
Total & 104 & $3,31231 \mathrm{E}+16$ & & & \\
\hline
\end{tabular}

$\mathrm{Y}=3118844+1621$ Umur $\left(\mathrm{X}_{1}\right)-2035874$ DJ (jenis kelamin $\left.\left(X_{2}\right)\right)$ - 258883 Jumlah Tanggungan Keluarga $\left(X_{3}\right)+1945254$ DP1 (pendidikan $\left(X_{4}\right)$ ) 50376 DP2 $\left(X_{4}\right)+585002$ DP3 $\left(X_{4}\right)+75110$ DP4 $\left(X_{4}\right)$ + 196370 Lama Usaha (tahun) $\left(X_{5}\right)+0,272$ Tingkat laba bersih per bln $\left(\mathrm{X}_{6}\right)-3270250$ DU1(jenis usaha $\left.\left(X_{7}\right)\right)$ - 935714 DU2 $\left(X_{7}\right)$ - 27226 Frekuensi Pinjaman $\left(X_{8}\right)+0,510$ Jumlah Pembiayaan yang diajukan $\left(X_{9}\right)+0,0822$ Nilai Agunan $\left(X_{10}\right)$.

Keterangan:

$\mathrm{X}_{1}=$ Umur

$\mathrm{X}_{2}=$ Jenis Kelamin. Boneka $1=$ perempuan dan $0=$ laki-laki

$\mathrm{X}_{3}=$ Jumlah Tanggungan Keluarga

$\mathrm{X}_{4}=$ Pendidikan .

DP1 : 1 = SD, 0 = selain SD

DP2 : $1=$ SMP , $0=$ selain SMP

DP3 : $1=$ SMA, $0=$ selain SMA

DP4 : $1=$ D3, $0=$ selain D3

$\mathrm{X}_{5}=$ Lama Usaha

$\mathrm{X}_{6}=$ Tingkat Laba Bersih per Bulan

$\mathrm{X}_{7}=$ Jenis Usaha.

DU1: 1 = perdagangan, $0=$ selain perdagangan

DU2 : 1 = manufaktur, 0 = selain manufaktur $\mathrm{X}_{8}=$ Frekuensi Pinjaman
$\mathrm{X}_{9}=$ Jumlah Pembiayaan yang Diajukan

$\mathrm{X}_{10}=$ Nilai Agunan

Dari persamaan regresi di atas, dapat diinterprestasikan tiap-tiap peubah yang memengaruhi realisasi pembiayaan mikro sebagai berikut:

1. Jenis usaha (perdagangan)

Arti dari model regresi untuk jenis usaha perdagangan adalah jika jenis usaha nasabah adalah perdagangan, maka realisasi pembiayaan akan turun 3.270.250. Hal tersebut terjadi karena dikhawatirkan dalam usaha perdagangan debitur memiliki banyak stok dan terjadi penumpukan akibat tidak laku. Selain itu, jenis usaha perdagangan tidak mengandung sesuatu yang unik, karena banyak yang menjalankan usaha sejenis dan memiliki banyak pesaing. Oleh karena itu, jika usaha debitur adalah perdagangan, maka realisasi pembiayaan akan turun dibandingkan jika jenis usaha debitur adalah manufaktur atau jasa.

2. Jumlah pembiayaan yang diajukan

Arti dari model regresi untuk jumlah pembiayaan yang diajukan adalah jika jumlah pembiayaan naik satu satuan, maka realisasi pembiayaan naik 0,510. Hal tersebut terjadi 
karena ketika debitur mengajukan pembiayaan, bank akan menyetujui pembiayaan $85 \%$ dari kebutuhan nasabah, sehingga ketika debitur mengajukan tinggi, maka realisasi pembiayaan akan naik.

\section{Nilai agunan}

Arti dari model regresi untuk nilai agunan adalah jika nilai agunan naik satu satuan, maka realisasi pembiayaan akan naik 0,0822. Hal tersebut terjadi karena semakin besar nilai agunan, akan semakin besar tanggung jawab debitur dalam melakukan pembayaran pinjaman pembiayaan yang diajukan. Selain itu, agunan merupakan second way out yang harus menutupi pinjaman $\geq 100 \%$, sehingga semakin besar nilai agunan, maka semakin besar pula pinjaman yang diberikan. Maka, jika nilai agunan besar, tentunya realisasi pembiayaan naik.

\section{KESIMPULAN}

Karakteristik debitur pembiayaan mikro BSM KCP Bogor Merdeka didominasi oleh pria, dan usia mayoritas nasabah pada usia 31-40 tahun. Tingkat pendidikan mayoritas nasabah adalah SMA. Jumlah tanggungan keluarga rataan 3-4 orang, biasanya terdiri dari suami/istri dan anak. Lama usaha nasabah mikro BSM KCP Bogor Merdeka sudah di atas 2 tahun dan mayoritas $<5$ tahun. Untuk laba bersih per bulan mayoritas nasabah Rp1.000.000-Rp5.000.000. Jenis usaha didominasi oleh sektor perdagangan. Mayoritas frekuensi pinjaman nasabah adalah 1-3 kali dan jumlah pembiayaan yang diajukan <= Rp20.000.000. Nilai agunan dari mayoritas nasabah <= Rp50.000.000, karena pembiayaan yang diajukan tidak terlalu besar dan rataan aset pengusaha mikro memang tidak terlalu besar dan untuk jenis penggunaan pembiayaan banyak digunakan untuk produktif (modal usaha atau investasi) dibandingkan untuk konsumtif.

Dari hasil penelitian terdapat tiga peubah yang memengaruhi realisasi pembiayaan mikro pada BSM KCP Bogor Merdeka, yaitu jenis usaha (perdagangan), jumlah pembiayaan yang diajukan dan nilai agunan.

\section{DAFTAR PUSTAKA}

Anggraini, D dan Nasution SH. 2013. Peranan Kredit Usaha Rakyat (KUR) Bagi Pengembangan UMKM di Kota Medan (Studi Kasus Bank BRI). Jurnal Ekonomi Pembangunan USU, 1 (3): 105-116..

[BPS] Badan Pusat Statistik. 2009. Data Pelaku Usaha Di Indonesia [Internet]. [diunduh 2013 Juni 11]. Tersedia pada: http://www.bps.go.id.

[BSM] Bank Syariah Mandiri. 2013. Data Outlet Warung Mikro. Jakarta (ID) : BSM.

Gujarati, D. 2007. Dasar-Dasar Ekonometrika. Jakarta (ID): Erlangga.

Iriawan, N dan Astuti SP. 2006. Mengolah Data Statistik Dengan Mudah Menggunakan Minitab 14. Yogyakarta (ID): CV Andi Offset.

Kasmir. 2013. Bank Dan Lembaga Keuangan Lainnya. Cetakan Keduabelas. Jakarta (ID): Raja Grapindo Persada.

[KEMEN KUKM] Kementrian Negara Koperasi dan Usaha Kecil dan Menengah. 2012. Indikator Makro Usaha Kecil dan Menengah. Jakarta (ID): Kemen KUKM.

Lubis, AM dan D. Rachmina. 2011. Faktor-Faktor yang Memengaruhi Realisasi dan Pengembalian Kredit Usaha Rakyat. Jurnal Forum Agribisnis, 1 (2): 112-131.

Nawai, N. dan M. N. M. Shariff. 2011. The Importance of Micro Financing to the Microenterprises Development in Malaysia. Asian Social Science, 7 (12): 226-238.

Nazir, M. 2003. Metodologi Penelitian. Jakarta (ID): Ghalia Indonesia.

Nurmanaf, A. R. 2007. Lembaga Informal Pembiayaan Mikro Lebih Dekat dengan Petani. Analisis Kebijakan Pertanian, 5 (2): 99-109.

Pato, S. 2013. Analisis Pemberian Kredit Mikro Pada Bank Syariah Mandiri Cabang Manado. Jurnal Riset Ekonomi, Manajemen, Bisnis dan Akutansi, 1 (4): 875-885.

Sunyoto, D. 2011. Analisis Regresi dan Uji Hipotesis. Yogyakarta (ID): CAPS. 